\title{
Production of Sterilized Medium Chain Length Polyhydroxyalkanoates (Smcl- PHA) as a Biofilm to Tissue Engineering Application
}

\author{
Anteneh Getachew ${ }^{1}$, Admas Berhanu ${ }^{1}$ and Andualem Birhane ${ }^{2}$ \\ ${ }^{1}$ Department of Biotechnology, College of Natural and Computational Sciences, Wolkite University, Wolkite, Ethiopia \\ ${ }^{2}$ Department of Biology, College of Natural and Computational Sciences Arba Minch University, Arba Minch, Ethiopia
}

\begin{abstract}
The current increase in the utilization of polyhydroxyalkanoates (PHAs) in various industrial and biomedical applications is due to their biodegradability, compatibility, resorbability and piezoelectricity. In the present study, we developed a modified medium chain length PHAs (Mmcl-PHA) by sterilizing surfaces of PHAs extracted from bacterial isolate. FTIR analysis of the neat polymer confirmed the presence of functional groups corresponding to alkyl halide, alkyne, hydroxyl group, and alkane groups. Sterilization of PHA using ethylene oxide as a medium was resulted modification of minor band differences in the absorption spectrum of homopolymer of PHB (scl-PHA) in to the co polymer of $\mathrm{P}(\mathrm{HB}-\mathrm{co}-\mathrm{HV})$ medium chain $(\mathrm{mcl}-\mathrm{PHA})$. The variation on to carbonyl $(\mathrm{C}=\mathrm{O})$ ester groups modified without significant changes to physico-chemical properties of the polymer were noticed. Sterilization of PHA using ethylene oxide has been evident surface modification properties suited to tissue engineering application of scaffold fabrication.
\end{abstract}

Keywords: Polyhydroxyalkanoates; Sterilization; Modification

\section{Introduction}

Polyhydroxyalkanoates (PHAs) are a category of natural polyesters as energy reserves in several species of microorganisms. They are wholly biodegradable, biocompatible and piezoelectric biopolymers that have attracted much attention recently as the biomaterial of choice for medical applications [1]. Polyhydroxyalkanoates can be considered as the natural biodegradable biomaterials used in different human clinical conditions. These biopolymers, due to their bioactive properties, they tend to have greater biological interaction with the cells, which allow them to have better performance in the biological system [2]. Adequate investigations have now been suggest PHA biopolymers promise to have a significant role in tissue engineering and the development of novel living tissue products for therapeutic applications [2,3]. These pledges of PHAs are due to it characteristics of biocompatible, support cell growth, guide and organize the cells, allow tissue in growth and, ultimately and degrade to non-toxic products [4].

Tissue engineering approaches employs scaffolds surface to be conducive to cell attachment and subsequent tissue growth [5]. This scaffolding composed of natural materials is commonly used as scaffolds to interact with biological systems to accomplish desirable medical outcomes in modern healthcare, providing alternatives to overcome the limitations and restrictions imposed by the use of autograft and allograft tissues [6]. Reactive polymer blending is one of the most economic and versatile way to produce materials combining the desired properties through forming the compatibilizing agents by inducing the chemico-physical interactions between polymer blends [7]. Hence, surface properties of PHAs have to be suited using different sterilization methods without altering its mechanical strength or thermal properties. Expectations for use of these scaffolds are increasing as the knowledge regarding their chemical and biological properties expands, and new biomedical applications are investigated [8].

Numerous surface modification techniques have been discovered and used deliberately for tissue engineering applications. To mention only a few, such modification techniques include gas plasma, Alfa radiation and ethylene oxide as well as the use of different chemicals, acids and bases were investigated $[9,10]$. The aim of this work has focused on production of PHAs polymer from bacterium isolated from different sample source. The polymer was further modified using ethylene oxide treatment and, the monomers for the scaffold requirements have been fabricated and subsequently characterized using FTIR spectroscopy.

\section{Methods}

\section{Isolation of bacterial strains}

Ten different samples were collected from different localities around Arba Minch town (sewage sludge, waste water and river sludge). The samples were used for isolation of bacteria by serially dilution techniques $\left(\mathrm{S}^{-1}\right.$ to $\left.\mathrm{S}^{-6}\right)$ in nutrient agar medium. The isolated bacterial colonies were screened and potential isolates were preserved on nutrient agar slants and glycerol stocks, until further use [11].

\section{Screening of PHAs producing bacterial strains}

The relative occurrences of PHAs accumulating bacteria from samples were studied by microscopic screening by Sudan Black B staining and florescent staining of acridine orange. The accumulation of PHAs in the isolates was ranked according to Nandini et al. [9] screening method. The black and yellow stained isolates were ranked in terms of + symbol. The medium stained colonies as ++ symbol, strongly stained colonies as +++ symbol while excellently stained as ++++ symbol.

\section{Quantification of PHAs and selection of one best isolate}

For screening of one best isolate, PHAs extracted from each isolate measured and one best isolate was selected. For production of PHAs mineral salt medium (MSM) was used for fermentation process. The medium MSM contained the following ingredients $(\mathrm{g} / \mathrm{L})$ : Urea (1.0), Yeast extract (0.16), $\mathrm{KH}_{2} \mathrm{PO}_{4}(1.52), \mathrm{Na}_{2} \mathrm{HPO}_{4}(4.0), \mathrm{MgSO}_{4} .7 \mathrm{H}_{2} \mathrm{O}$ (0.52), $\mathrm{CaCl}_{2}$ (0.02), Glucose (40), and trace element solution 0.1

${ }^{*}$ Corresponding author: Anteneh Getachew Woldemariam, Wolkite University, Department of Biotechnology, P.O. Box -07, Wolkite, Ethiopia, Tel: +251-0913429224 Email: antutensu@gmail.com

Received May 04, 2016; Accepted April 25, 2016; Published May 02, 2016

Citation: Getachew A, Berhanu A, Birhane A (2016) Production of Sterilized Medium Chain Length Polyhydroxyalkanoates (Smcl- PHA) as a Biofilm to Tissue Engineering Application. J Tissue Sci Eng 7: 167. doi:10.4172/2157-7552.1000167

Copyright: (c) 2016 Getachew A, et al. This is an open-access article distributed under the terms of the Creative Commons Attribution License, which permits unrestricted use, distribution, and reproduction in any medium, provided the original author and source are credited. 
Citation: Getachew A, Berhanu A, Birhane A (2016) Production of Sterilized Medium Chain Length Polyhydroxyalkanoates (Smcl- PHA) as a Biofilm to Tissue Engineering Application. J Tissue Sci Eng 7: 167. doi:10.4172/2157-7552.1000167

ml. Trace element solution contained $(\mathrm{g} / \mathrm{L}): \mathrm{ZnSO}_{4} \cdot 7 \mathrm{H}_{2} \mathrm{O}(0.13)$, $\mathrm{FeSO}_{4} .7 \mathrm{H}_{2} \mathrm{O}(0.02),\left(\mathrm{NH}_{4}\right)_{6} \mathrm{MO}_{7} \mathrm{O}_{24} \cdot 4 \mathrm{H}_{2} \mathrm{O}(0.06)$ and $\mathrm{H}_{3} \mathrm{BO}_{3}(0.06)$. Both glucose and trace element solution were autoclaved separately, and reconstituted prior to inoculation. For PHAs production, $100 \mathrm{~mL}$ of production medium was inoculated with $1 \mathrm{~mL}$ of the organism. All the flasks were incubated on a shaker incubator at $37^{\circ} \mathrm{C}$ and 150 $\mathrm{rpm}$ for $48 \mathrm{hrs}$ and the process was triplicated. Cells were collected by centrifuging at $10,000 \mathrm{rpm}$ for $15 \mathrm{~min}$, samples dried at $55^{\circ} \mathrm{C}$ to constant weight $[12,13]$. Quantification of PHAs has been done by crotonic acid assay of standard curve the method described by Burdon [14]. Then concentrated (98\%) of $10 \mathrm{ml}$ hot $\mathrm{H}_{2} \mathrm{SO}_{4}$ was added to the polymer granules. The addition of sulfuric acid converts the polymer into crotonic acid, which is brown colored. The solution was cooled and the absorbance read at $235 \mathrm{~nm}$ against a sulfuric acid blank. By referring to the standard curve, the quantity of PHAs produced was determined and calculated using the following formula.

Residual biomass $(\mathrm{g} / \mathrm{L})=$ Dry Cell Weight $(\mathrm{g} / \mathrm{L})$ - Dry weight of extracted PHA $(\mathrm{g} / \mathrm{L})$

PHA accumulation $(\%)=$ Dry weight of extracted PHA $(g / L) /$ Dry Cell Weight $(\mathrm{g} / \mathrm{L}) \times 100 \%$

\section{Characterization of PHAs producing isolate}

The positive PHAs producing bacterial isolates were subjected to a set of morphological, physiological and biochemical tests for identification. Biochemical characterization was done according to Bergey's Manual of Determinative Bacteriology.

\section{Preparation of biofilm}

PHA film was prepared by homogenizing $370 \mathrm{mg}$ each of a PHA powder with PEG, glycerol in $40 \mathrm{ml}$ of chloroform. The solutions were poured onto glass plate and dried at $30^{\circ} \mathrm{C}$ to obtain the films [15].

\section{PHA sterilization using ethylene oxide}

The biofilm further modified using the concept of the ethylene oxide treatment technique described by Marois et al., 1999 [10]. Biofilm treated with ethylene oxide for $8 \mathrm{hrs} 38^{\circ} \mathrm{C}$ with $65 \%$ humidity and subsequent measurement of changes within functional groups of treated polymer was quantified using FTIR.

\section{Fabrication of PHA scaffolds}

For fabrication of PHA, dispersing of a leachable material within a scaffolding material was required. Subsequently, fabricating the required material, shape, and then removing the leachable material to leave a porous scaffold [9].

\section{PHA authentication}

FTIR spectroscopy was used to record the PHA spectrum on the range of a scan 400 to $4000 \mathrm{~cm}$ at room temperature $\left(27^{\circ} \mathrm{C}\right)$ was applied. A $0.01 \mathrm{~g}$ of the biofilm sample was prepared in dichloromethane and the mixture was then applied on to the $\mathrm{NaCl}$ crystal window and the spectrum was read after the solvent has been dried [16].

\section{Results}

\section{Isolation of bacterial strain}

A total of 15 representative colonies of bacteria isolated from 3 sampling areas. The isolated colonies were taken from $10^{-4}$ serial dilution of nutrient agar plate. The colonies were purified by repeated streaking on nutrient agar medium. Each colony of pure culture was individually picked based on distinct morphological characteristics and subjected to screening procedure of PHAs production.

\section{Screening and characterization of PHAs producing strains}

The relative occurrences of PHAs accumulating bacteria from samples were studied. A striking prevalence of PHAs producing bacteria was observed in wastewater sample. Out of the 20 bacterial isolates obtained from 15 samples, three isolates were showed positive response to staining procedures by accumulation of PHAs granule inside the cell (Figure 1). Screening procedures such as Sudan black and fluorescent staining results depicted in

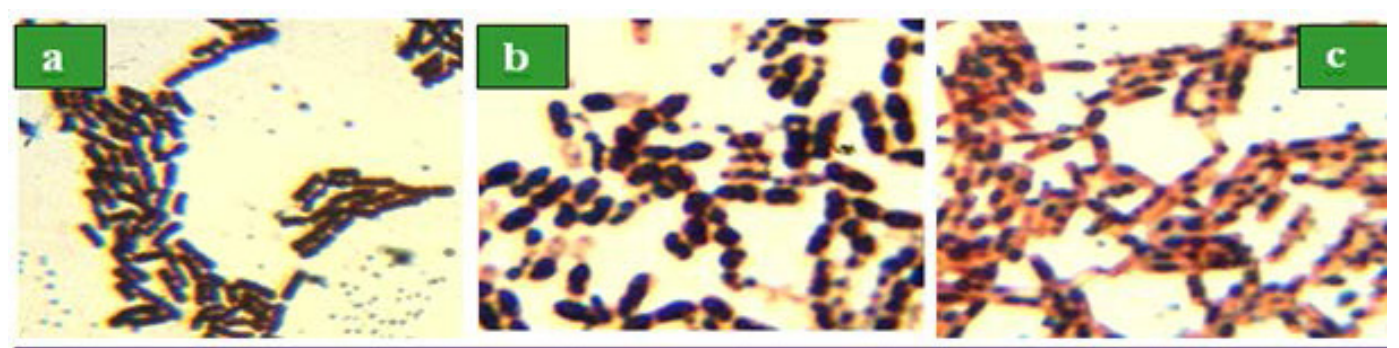

Photomicrographv of Sudan Black B staining of isolates a) WW b) SS c) RS

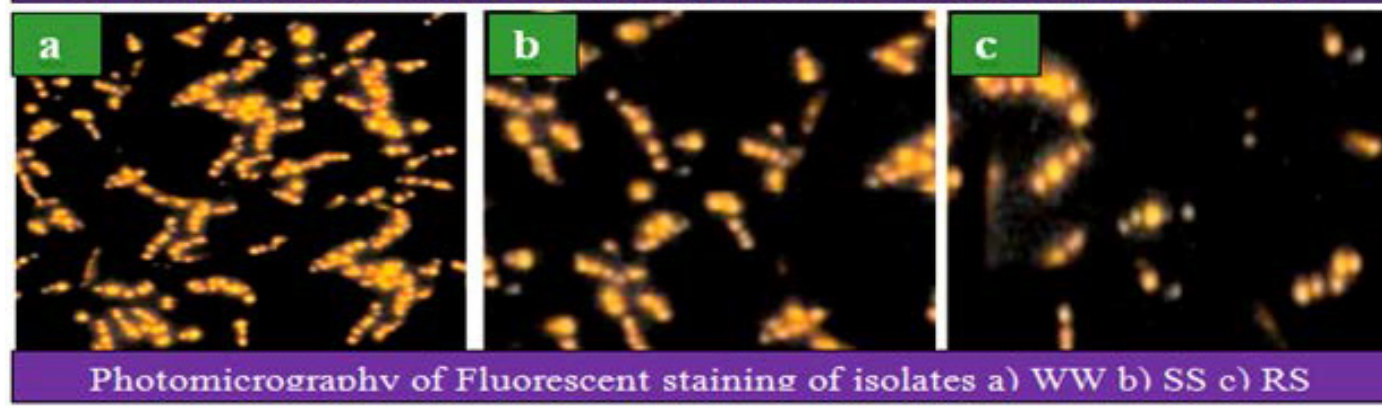

Figure 1: Photomicrography of Sudan Black B and Fluroescent staining of acridine orange of isolates. 
Citation: Getachew A, Berhanu A, Birhane A (2016) Production of Sterilized Medium Chain Length Polyhydroxyalkanoates (Smcl- PHA) as a Biofilm to Tissue Engineering Application. J Tissue Sci Eng 7: 167. doi:10.4172/2157-7552.1000167

Page 3 of 5

\begin{tabular}{|c|c|c|c|c|c|c|c|}
\hline \multirow[b]{2}{*}{ Sample source } & \multirow[b]{2}{*}{$\begin{array}{l}\text { Designation } \\
\text { of Isolates }\end{array}$} & \multicolumn{4}{|c|}{ Biochemical characteristics } & \multicolumn{2}{|c|}{ PHA Accumulation } \\
\hline & & Endospore & $\begin{array}{l}\text { Gram } \\
\text { Staining }\end{array}$ & $\begin{array}{l}\text { Catalase } \\
\text { Production } \\
\text { Utilization }\end{array}$ & Citrate & $\begin{array}{l}\text { Sudan } \\
\text { Black B }\end{array}$ & $\begin{array}{l}\text { FIFluorescent } \\
\text { staining }\end{array}$ \\
\hline Waste water & WW & $+\mathrm{Ve}$ & $+\mathrm{Ve}$ & $-V e$ & $+\mathrm{Ve}$ & ++++ & ++++ \\
\hline Sewage sludge & SS & $-V e$ & $+\mathrm{Ve}$ & $+\mathrm{Ve}$ & $+\mathrm{Ve}$ & +++ & +++ \\
\hline River sludge & RS & $+\mathrm{Ve}$ & $+\mathrm{Ve}$ & $-\mathrm{Ve}$ & $-V e$ & ++ & ++ \\
\hline
\end{tabular}

Table 1: Biochemical characteristics and screening of isolates.

Table 1. The strains also subjected to biochemical characterization, from the result all isolates found as bacillus species (Table 1).

\section{Selection of one best isolate}

The isolates were further compared and screened by the amount of PHAs they produced utilizing glucose as a sole carbon source in their growth medium. The better PHAs producing isolates were identified based on the amount of cell dry weight of extracted PHA (Table 1). Isolate $\mathrm{WW}$ was selected for further studies as it produced the highest amount $46.28 \%$ cell dry weight of PHA.

\section{Biofilm production and surface modification}

PHA powder has been used as a matrix for production of a neat biofilm sheet. The neat biofilm sheet was further modified by using ethylene oxide treatment to suit its surfaces for tissue engineering application. On surface analysis, the blends exhibited higher values of roughness compared with the neat films (Figure 2).

\section{Scaffold fabrication}

Surface modified biofilm was subjected to scaffold fabrication. The scaffolds were fabricated by using waxy components for intended shape and the component subsequently separated. The scaffolds fabricated for different tissue engineering applications are depicted in Figure 3.

\section{PHAs authentication}

FTIR spectroscopy was used to record the PHA spectrum on the range of a scan 400 to $4000 \mathrm{~cm}$ was applied. Both neat and modified form of polymers resulted in different peaks assigned for functional groups as shown below in Figure 4.

\section{Discussion}

\section{Isolation screening and characterization of PHA producing strains}

In present study potential PHAs polymer accumulating bacteria were isolated from diverse sources and the efficient strain was selected for further studies (Table 1). Among 15 bacterial isolates, 3 were able to produce PHAs which was confirmed by Sudan black B and fluorescence staining by observing the presence of granule inside the cell. Significant PHAs was produced by isolates from wastewater. The morphological
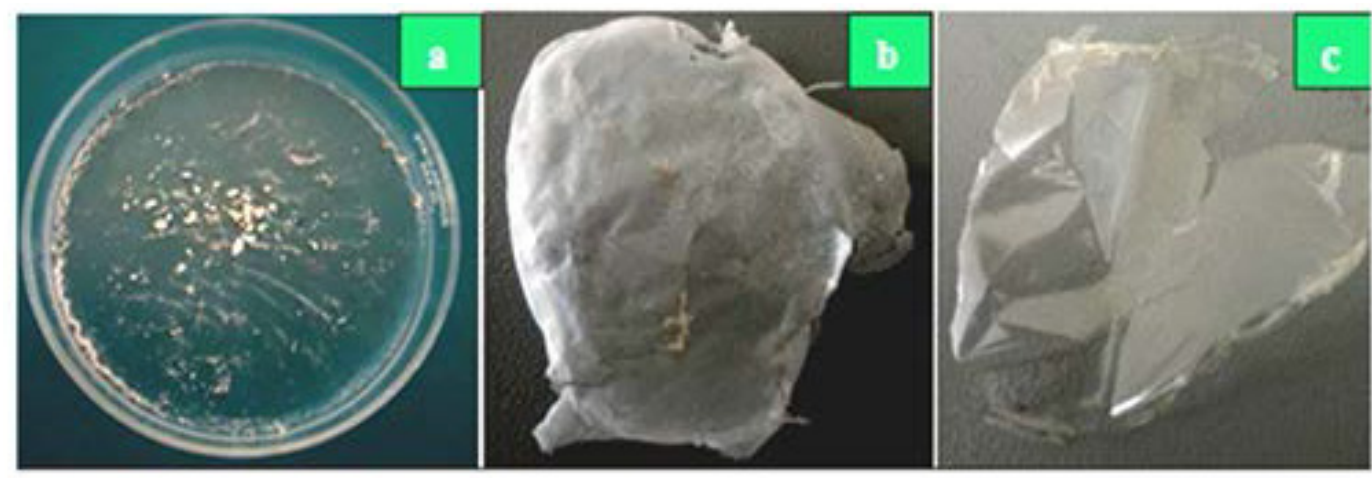

Figure 2: PHAs Polymer a) powder polymer extracted from bacterial isolate b) The neat biofilm sheet produced by chloroform method c) Modified form of the neat film blends using ethylene oxide.
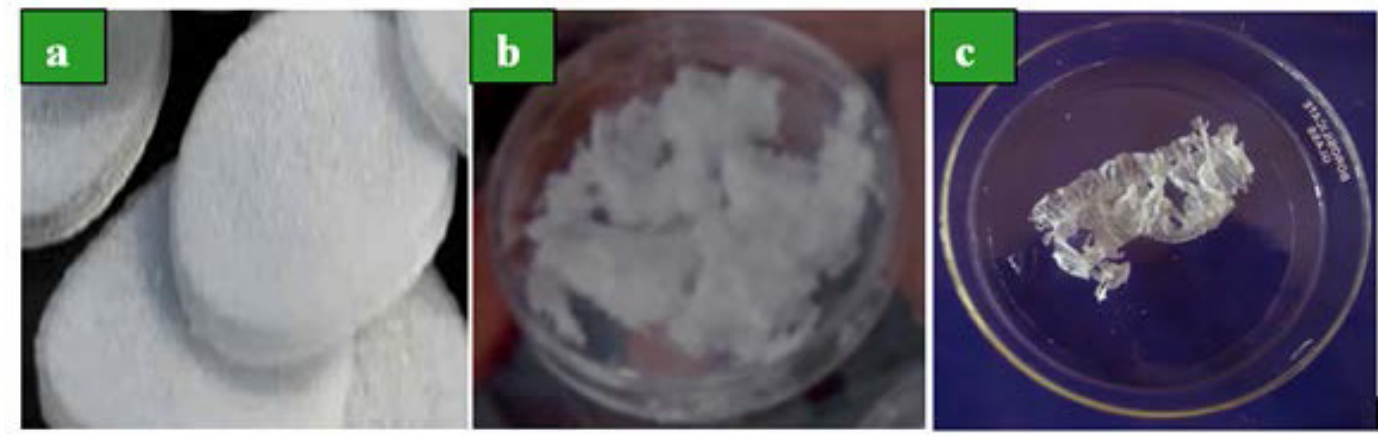

Figure 3: Examples of PHAs scaffodls fabricated for tissue engineering applications, a) Meshes b) Woven c) Fibers. 

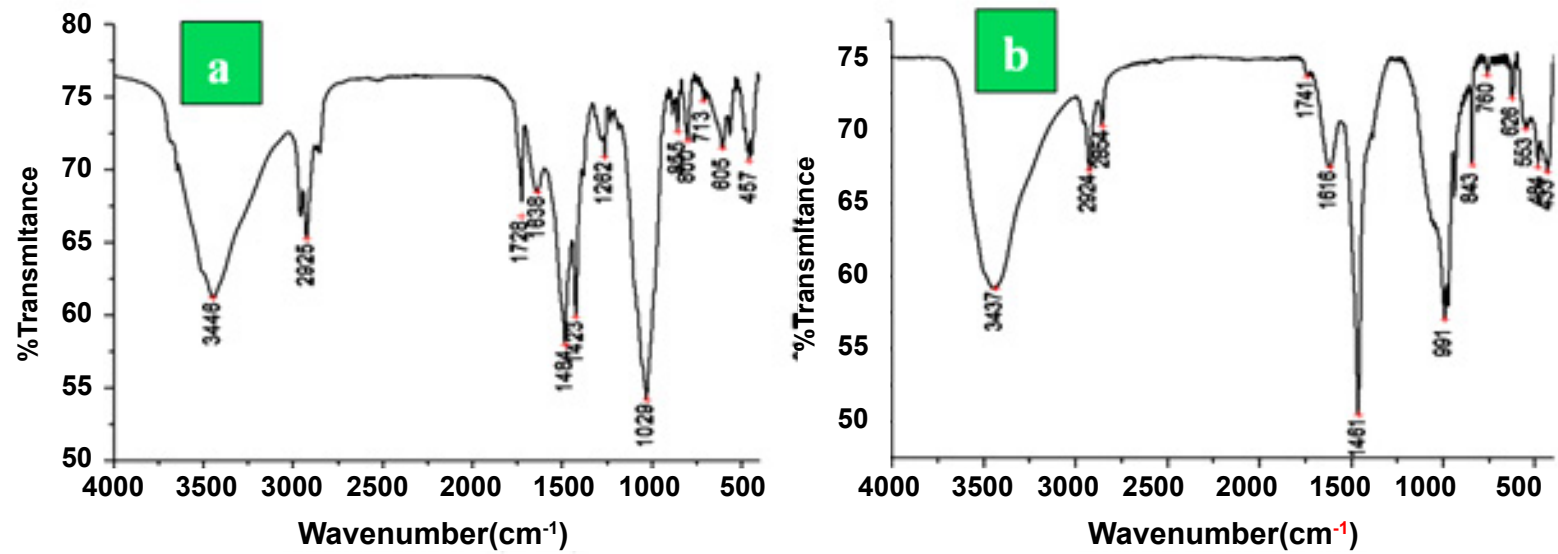

Figure 4: FTIR analysis (a)scl- PHA (P3HB)extracted from isolate WW (b) modified mcl-PHA P(HB-co-HV) using ethylene oxide as medium.

\begin{tabular}{|c|c|c|c|c|c|}
\hline Isolates & $\begin{array}{c}\text { Growth at } \\
\text { 600nm }\end{array}$ & $\begin{array}{c}\text { PHA } \\
\text { (g/l) }\end{array}$ & $\begin{array}{c}\text { Dry weight } \\
\mathbf{( g / l )}\end{array}$ & $\begin{array}{c}\text { Residual } \\
\text { Biomass (g/l) }\end{array}$ & $\begin{array}{c}\text { PHA \% } \\
\text { (w/w) }\end{array}$ \\
\hline WW & 1.159 & $5.0 \pm 0.44$ & $12.0 \pm 0.08$ & $7.0 \pm 0.05$ & 46.28 \\
\hline SS & 1.125 & $3.9 \pm 0.03$ & $11.0 \pm 0.00$ & $7.1 \pm 0.13$ & 35.45 \\
\hline RS & 0.991 & $3.2 \pm 0.07$ & $9.4 \pm 0.001$ & $6.2 \pm 0.39$ & 34.04 \\
\hline
\end{tabular}

Data represent the mean of 3 different replicates \pm standard deviation.

Table 2: PHAs accumulated by the 3 selected isolates after $48 \mathrm{hrs}$ of incubation at $37^{\circ} \mathrm{C}$ and $\mathrm{pH} 7.0$ using shake flasks as a batch culture.

and biochemical characterization of isolates and their probable genera are depicted in Table 1. Most isolates found were Bacillus species. As such, similar results were reported bacillus species as an ideal PHA producer $[17,18]$. One best isolate was selected based on the amount of PHAs accumulation inside the cell. Hence, isolate WW was found to be a promising bacterium which produced $(46.28 \% \mathrm{CDW})$ of PHAs and selected for further experiments (Table 2).

\section{Surface modification scaffold production and PHAs authentication}

Surface properties of any medical device are exceedingly important to interact with the host. As such, tissue engineering approaches employs cell seeded scaffolds that are essential and having surfaces conducive to cell attachment and subsequent tissue growth. Useful surface modification includes changes in chemical group functionality, surface charge, hydrophobicity, hydrophilicity and wettability [19]. In present study, PHAs biofilm produced from bacterial isolate was further modified using ethylene oxide treatment. Result obtained from the experiment was evident, surface properties of PHAs have been suited without altering other properties of the scaffold. Change in functional groups of the polymer blends quantified using FTIR spectroscopy and depicted in figure 4 . The fabrication of a suitable scaffold using leachable material has been prepared and depicted in (Figure 2). Significant amount of work has been focused on identifying suitable scaffold configurations for tissue engineering applications. Study reported by Lorena et al. [19] evident, PHA polymer surface was modified by using the solvent-casting method. Using this method the resultant copolymers such as poly (3-hydroxybutyrate), $\mathrm{P}(3 \mathrm{HB})$, and poly(3-hydroxybutyrate-co-3-hydroxyhexanoate) ( $\mathrm{P}(3 \mathrm{HB}-\mathrm{co}-3 \mathrm{HHx})$ ) have been explored for use in nerve regeneration. Another study reported by Ralf et al. [8] was noted a scaffold for a trileaflet heart valve using a thermoplastic polyester modified by a salt leaching technique. In this study, a heart valve scaffold was constructed from a thermoplastic

elastomer known as PHAs. The PHAs extracted through fermentation was modified by a salt leaching technique to create a porous, threedimensional structure, suitable for tissue engineering has been noticed.

FTIR is one of the rapid and powerful tools to obtain information on polymer structure. Because every chemical compound in the sample is makes its own distinct contribution to the absorbance/transmittance spectrum [15]. The method is particularly suitable for screening a large number of bacterial cells and it has been demonstrated that PHA present within the cells can be rapidly detected by this technique $[15,19]$. In the present study, the observed infrared absorption at 3446 and $3437 \mathrm{~cm}^{-1}$ was assigned to the hydroxyl group of the polymer chain of both purified and modified polymers respectively [20]. The absorption band at 2925 and $2924 \mathrm{~cm}^{-1}$ was assigned to asymmetric $\mathrm{C}-\mathrm{H}$ stretching vibrations of methyl groups of both polymers. A shift in $\mathrm{CH}_{2}$ of the lateral monomeric chains was assigned to the stretching vibration at $2854 \mathrm{~cm}^{-1}$ has not appeared on the scl- PHA (Figure 4a). Although the absorption bands of 1728 and $1741 \mathrm{~cm}^{-1}$ has been reported to be a PHA marker band assigned to carbonyl $(\mathrm{C}=\mathrm{O})$ stretch of the ester groups present in the molecular chain of highly ordered crystalline structures according to Randriamahefa et al. [21]. These peaks were comparable with the standard peaks 1728 and $1740 \mathrm{~cm}^{-1}$ to scl-PHA and mcl-PHA respectively [22]. Short-chain length PHA represents (scl-PHA; 3 to 5 carbon atoms) and medium-chain length PHA (mclPHA; 6 to 14 carbon atoms) monomer units [23]. This kind of PHA is bearing different functional groups that can be modified by chemical reaction to obtain useful polymer and the monomer usually used for medical application of tissue engineering [18]. Minor band differences in the absorption spectrum of homopolymer of $\mathrm{PHB}$ and Co polymers of $\mathrm{P}(\mathrm{HB}-\mathrm{co}-\mathrm{HV})$ in ethylene oxide as a medium were noticed. Hence, the variation on to carbonyl $(\mathrm{C}=\mathrm{O})$ ester groups evident sterilization of biofilm using ethylene oxide has been modified without significant changes to physico-chemical properties of the polymer. The monomers of this kind of PHA could be given lower melting point and crystallinity to polymer and conducive to cell attachment and subsequent tissue growth (Figure $4 \mathrm{~b}$ ).

P3HB homopolymer had characteristic absorption bands of 1638 and $1484 \mathrm{~cm}^{-1}$, while copolymer of $\mathrm{P}(\mathrm{HB}-\mathrm{co}-\mathrm{HV})$ showed a shift in $\mathrm{N}-\mathrm{H}$ amid protein in 1616 and $1431 \mathrm{~cm}^{-1}$. Absorption at $1423 \mathrm{~cm}^{-1}$ is owed to a terminal $\mathrm{CH}_{3}$ group of PHB [24,25], while that was not appearing at copolymer $\mathrm{P}(\mathrm{HB}-\mathrm{co}-\mathrm{HV})$. The peak at $1262 \mathrm{~cm}^{-1}$ owes asymmetric $\mathrm{C}-\mathrm{O}-\mathrm{C}$ stretches vibration present on $\mathrm{PHB}$. Moreover, series of absorption bands at $1029 \mathrm{~cm}^{-1}$ to $457 \mathrm{~cm}^{-1}$ were assigned 
Citation: Getachew A, Berhanu A, Birhane A (2016) Production of Sterilized Medium Chain Length Polyhydroxyalkanoates (Smcl- PHA) as a Biofilm to Tissue Engineering Application. J Tissue Sci Eng 7: 167. doi:10.4172/2157-7552.1000167

Page 5 of 5

to $\mathrm{C}-\mathrm{O}$ and $\mathrm{C}-\mathrm{C}$ stretches of amorphous phase [26,27]. These series absorptions showed shift to $991 \mathrm{~cm}^{-1}$ to $433 \mathrm{~cm}^{-1}$ at copolymer P (PHBco-HV).

\section{Conclusion}

The present study illustrated extraction and sterilization of PHAs produced by a bacterial isolate. Analysis of functional group using FTIR evident, absorption bands of 1728 and $1741 \mathrm{~cm}^{-1}$ of PHA marker bands assigned to carbonyl $(\mathrm{C}=\mathrm{O})$ were comparable with the standard peaks 1728 and $1740 \mathrm{~cm}^{-1}$ to scl-PHA and mcl-PHA respectively. Ethylene oxide was used as a potential chemical for sterilization and subsequent modification of PHA for fabrication of tissue scaffolds. In modification treatment the absorption band of homopolymer of PHB shifted to co polymers of $\mathrm{P}(\mathrm{HB}-\mathrm{co}-\mathrm{HV})$ in ethylene oxide as a medium. Other shifts were also observed absorptions assigned to $\mathrm{CH}_{2}, \mathrm{C}-\mathrm{O}, \mathrm{C}-\mathrm{C}$ and $\mathrm{N}-\mathrm{H}$ amid protein. Additionally, shift in $\mathrm{CH}_{2}$ of the lateral monomeric chains were assigned to the stretching vibration at $2854 \mathrm{~cm}^{-1}$ was not appearing on modified PHA. Therefore, this modification experiment of PHA evident surface properties to suit the intended application often without altering other properties of the scaffold. The functional groups registered on modified PHA such as (alkyl halide, alkyne, hydroxyl group, and alkane groups) were very suitable for attachments and growth of new proliferative cells.

\section{Acknowledgement}

The authors thank Department of Biology, Arba Minch University

\section{Conflict of interest}

The authors have not declared any conflict of interest.

\section{References}

1. Martin RV, Brenda VR, Rodrigo RZ, Daniel ASK, Luis FQO (2015) Chitosan and Its Potential Use as a Scaffold for Tissue Engineering in Regenerative Medicine. BioMed Research International: 15

2. Thomson N, Roy I, Summers D, Sivaniah E (2010) In vitro production of polyhydroxyalkanoates: achievements and applications. J Chem Technol Biotechnol 85: 760-767.

3. Rai R, Keshavarz T, Roether J, Boccaccini A, Roy I (2011) Medium chain length polyhydroxyalkanoates, promising new biomedical materials for the future. Mat Sci Eng R 72: 29-47.

4. Lu T, Li Y, Chen T (2013) Techniques for fabrication and construction of threedimensional scaffolds for tissue engineering. Int J Nanomedicine 8: 337-350.

5. Sultana N, Wang M (2012) PHBV/PLLA-based composite scaffolds fabricated using an emulsion freezing/freeze-drying technique for bone tissue engineering: surface modification and in vitro biological evaluation. Biofabrication 4: 1 .

6. Lizarbe MA (2007) Sustitutivos de tejidos: de los biomateriales a la ingenier'ia tisular. Rev R Acad Cienc Exact Fís Nat Esp 101: 227-249.

7. Ke Y, Zhang XY, Ramakrishna S, He LM, Wu G (2016) Reactive blends based on polyhydroxyalkanoates: Preparation and biomedical application. Materials Science and Engineering

8. Ralf S, Jason SS, David PM, Ana E, Ulrich S, et al. (2004) Technical Report: Fabrication of a Trileaflet Heart Valve Scaffold from a Polyhydroxyalkanoate Biopolyester for Use in Tissue Engineering. Tissue Engineering 6: 183-188.

9. Williams SF, Martin DP, Horowitz DM, Peoples OP (1999) PHA applications: addressing the price performance issue: I. Tissue engineering. Int $\mathrm{J}$ Biol Macromol 25: 111-121.

10. Marois Y, Zhang Z, Vert M, Deng X, Lenz R, et al. (1999) Effect of sterilization on the physical and structural characteristics of polyhydroxyoctanoate (PHO). J Biomater Sci Polym Ed 10: 469-482.

11. Arcos-Hernandez MV, Gurieff N, Pratt S, Magnusson P, Werker A, et al. (2010) Rapid quantification of intracellular PHA using infrared spectroscopy: an application in mixed cultures. J Biotechnol 150: 372-379.

12. Nandini P, Amruta C, Bhavesh P, Pragya R, Priti V, et al. (2011) Screening of
PHB (Polyhydroxyalkanoate) producing bacteria from diverse sources. Int $\mathrm{J}$ Biosci 6: 27-32.

13. Ji GZ, Wei X, Chen GQ (2009) Growth of human umbilical cord Wharton's Jellyderived mesenchymal stem cells on the terpolyester poly(3-hydroxybutyrateco-3-hydroxyvalerate-co-3-hydroxyhexanoate). J Biomater Sci Polym Ed 20: 325-339.

14. Burdon KL (1946) Fatty Material in Bacteria and Fungi Revealed by Staining Dried, Fixed Slide Preparations. J Bacteriol 52: 665-678.

15. Shamala TR, Divyashree MS, Reeta DL, Kumari KS, Vijayendra SVN, et al. (2009) Production and characterization of bacterial polyhydroxyalkanoate copolymers and evaluation of their blends by fouriertransform infrared spectroscopy and scanning electron microscopy. Indian J Microbiol 49: 251258.

16. Gumel AM, Annuar MS, Heidelberg T (2012) Biosynthesis and characterization of polyhydroxyalkanoates copolymers produced by Pseudomonas putida Bet001 isolated from palm oil mill effluent. PLoS One 7: e45214.

17. Full TD, Jung DO, Madigan MT (2006) Production of poly-betahydroxyalkanoates from soy molasses oligosaccharides by new, rapidly growing Bacillus species. Lett Appl Microbiol 43: 377-384.

18. Vishnuvardhan RS, Thirumala M, Mahmood S (2009) Production of PHB and $\mathrm{P}$ (3HB-co-3HV) biopolymers by Bacillus megaterium strain OU303A isolated from municipal sewage sludge. World J Microbiol Biotechnol 25: 391-397.

19. Lorena RLV, Rinat N, Caroline T, Haycock JW, Claeyssens F, et al. (2015) Nerve tissue engineering using blends of poly (3-hydroxyalkanoates) for peripheral nerve regeneration 15: 612-621.

20. Bonduelle C, Martin-Vaca B, Bourissou D (2009) Lipase-catalyzed ring opening polymerization of the O-carboxylic anhydride derived from lactic acid. Biomacromolecules 10: 3069-3073.

21. Randriamahefa S, Renard E, Guerin P, Langlois V (2003) Fourier transform infrared spectroscopy for screening and quantifying production of PHAs by Pseudomonas grown on sodium octanoate. Biomacromolecules 4: 1092-1097.

22. Hong K, Sun S, Tian W, Chen GQ, Huang W (1999) A rapid method for detecting bacterial Polyhydroxyalkanoates in intact cells by fouriertransform infrared spectroscopy. Appl Microbiol Biotechnol 51: 523-526.

23. Giin Yu AT, Chia Lung C, Ling L, Liya G, Lin W (2014) Start a research on biopolymer polyhydroxyalkanoate (PHB): A Review. Polymers 6: 706-754

24. Sha K, Li D, Li Y, Zhang B, Wang J (2008) The chemoenzymatic synthesis of a novel CBABC-type pentablock copolymer and its self-assembled "crew-cut" aggregation. Macromolecules 41: 361-371.

25. Galia MB (2010) Isolation and analysis of storage compounds. In: Timmis $\mathrm{KN}$ (ed). Handbook of Hydrocarbon and Lipid Microbiology. Springer: Berlin/ Heidelberg, Germany pp: 3725-3741.

26. Annuar MSM, Tan IKP, Ibrahim S, Ramachandran KB (2007) Production of medium-chain-length poly (3-hydroxyalkanoates) from crude fatty acids mixture by Pseudomonas putida. Food and Bioproducts Proc 85: 104-119.

27. Lu J, Tappel RC, Nomura CT (2009) Mini-review: Biosynthesis of poly (hydroxyalkanoates). Polym Rev 49: 226-248. 